\title{
KRYZYS (W) EDUKACJI I JEGO PRZEZW YCIĘŻENIE WEDŁUG JANA AMOSA KOMEŃSKIEGO I EMANUELA RÁDLA
}

Streszczenie: Wychowanie i kształcenie są współcześnie pogrążone w głębokim kryzysie. Żeby zrozumieć jego istotę i możliwości przezwyciężenia, autorka odwołuje się do myśli Jana Amosa Komeńskiego i Emanuela Rádla. Pomimo dystansu czasowego ich twórczość pedagogiczna pozostaje wciąż aktualna i inspirująca.

Artykuł składa się z trzech części. W pierwszej zrekonstruowano poglądy Komeńskiego odnośnie wychowania jako swoistego sposobu oddziaływania pedagogicznego i znaczenie wychowania w edukacyjnym procesie dochodzenia do pełni człowieczeństwa - tak przez jednostkę, jak i społeczeństwo. Druga część dotyczy postaci Rádla, XX-wiecznego przyrodoznawcy i filozofa, który - podobnie jak Komeński - zauważał problemy (w) edukacji i zastanawiał się nad sposobami ich rozwiązania. Na zakończenie skonfrontowano stanowiska obu myślicieli, poszukując inspiracji do przezwyciężenia współczesnego kryzysu (w) edukacji.

Słowa kluczowe: edukacja; wychowanie; kształcenie; Komeński; Rádl.

Tradycja czeskiej filozofii wychowania kryje w sobie wymiar uniwersalny, który można nazwać też holistycznym lub transcendentnym. W niniejszym artykule wymiar ten zostanie odczytany jako nieodłączna cecha wychowania. Żeby to ukazać, wybrałam dwóch wybitnych czeskich myślicieli - Jana Amosa Komeńskiego (1592-1670) i Emanuela Rádla (1873-1942). Ich spuścizna intelektualna znana jest daleko poza granicami Czech, zwłaszcza tego pierwszego. Chociaż należeli do różnych i odległych od siebie epok, łączy ich konsekwentne postulowanie tego, żeby edukacja była nie tylko przygotowaniem do rynku pracy, a więc kształtowała człowieka biegłego w sprawach praktycznych, lecz także aby była rozwijaniem potencjału duchowego złożonego w każdym wychowanku. Dzięki temu będzie on 
zdolny do znalezienia swojego miejsca w świecie jako swoistej całości, zadzierzgnięcia z nim łączności i pielęgnowania poczucia wspólnoty.

Oprócz powyższego zbieżne u Komeńskiego i Rádla jest moim zdaniem to, że obaj żyli i działali w trudnych czasach wielorakich kryzysów - politycznych, religijnych, wartości, duchowych, intelektualnych i kulturowych. Chociaż kryzysy te wyryły głębokie ślady tak w społeczeństwie czeskim, jak i europejskim, wskazani autorzy nie tracili nadziei na lepszą przyszłość. Wynikało to stąd, że na pojawiające się problemy patrzyli z perspektywy pedagogicznej i wskazywali rozwiązania uwzględniające wychowanie i kształcenie w danej epoce.

Prezentowane rozważania składają się z trzech części. W pierwszej zostaną zrekonstruowane poglądy Komeńskiego odnośnie wychowania jako swoistego sposobu oddziaływania pedagogicznego i jego znaczenia w edukacyjnym procesie zdobywania pełni człowieczeństwa tak przez jednostkę, jak i społeczeństwo. Druga część poświęcona została postaci Rádla, XX-wiecznego naukowca i filozofa, który - podobnie jak Komeński - dostrzegał problemy edukacji i zastanawiał się nad ich rozwiązaniem. Na zakończenie skonfrontowano stanowiska obu myślicieli, poszukując inspiracji do przezwyciężenia współczesnego kryzysu (w) edukacji.

\section{Edukacja jako „naprawianie rzeczy ludzkich”}

Jan Amos Komeński żył w XVII wieku. Jak wiadomo, był to okres zdominowany przez wojnę trzydziestoletnią - największą katastrofę nowożytnej Europy. Z tego powodu Komeński większość swojego życia musiał spędzić na wygnaniu. Przez pewien czas mieszkał również w polskim Lesznie, gdzie rozpoczął pisanie Pansophii. Swoimi dziełami przyczynił się do zreformowania szkolnictwa w Szwecji, Wielkiej Brytanii, na Węgrzech i w Holandii, nigdy jednak nie wrócił do swojej czeskiej ojczyzny. W tym kontekście przychodzi na myśl powiedzenie, zgodnie z którym nikt nie jest prorokiem we własnym kraju.

Sprawom wychowania i kształcenia Komeński poświęcił całe swoje życie. Do najważniejszych jego dzieł pedagogicznych należą: Labirynt świata i raj serca oraz Wielka dydaktyka. Był również autorem podręczników do nauczania języków, takich jak: Janua linguarum reserata (Drzwi języków otworzone) i Orbis pictus (Świat w obrazach, 2015). Jego głównym dziełem była jednak niedokończona praca pt. De rerum humanarum emendatione consultatio catholica (Ogólne zastanowienie się, jak naprawić sprawy człowieka). Nie należy jednak traktować Komeńskiego tylko jako pedagoga i teoretyka edukacji, ponieważ byłoby to sprzeczne z duchem jego twórczości. Duch ten objawia się wyraźnie w stwierdzeniu pochodzącym z jednego z jego nieprzetłumaczonych (jeszcze) na język polskich pism: „Wszystko, co napisałem jako nauczyciel, napisałem jako ksiądz” (Komenský 1957, s. 27).

Komeńskiego uważa się za pomysłodawcę nowoczesnej dydaktyki. Sądzę jednak, że nie zależało mu jedynie na udoskonaleniu sposobu nauczania poszczególnych przedmiotów. Jego pragnieniem było raczej zreformowanie kształcenia szkolnego 
tak, żeby dostosować je do specyfiki uczenia się. Komeński nie zawężał sensu nauki szkolnej do przygotowania uczniów do rzemiosła czy życia w społeczeństwie, chociaż niewątpliwie doceniał wiedzę praktyczną i świadomy był roli odgrywanej w jej zdobywaniu przez nauczanie. Używając współczesnego języka, należy stwierdzić, że nie chodziło mu również o demokratyzację szkolnictwa, mimo że często pisze się o tym w kontekście jego definicji dydaktyki jako uniwersalnej sztuki nauczania omnes omnia omnino, tzn. „wszystkich wszystkiego wszystkimi możliwymi środkami i w odniesieniu do całości”. Niewątpliwie jego pragnieniem było, żeby edukacja była osiągalna dla wszystkich i dlatego domagał się jako pierwszy - mówiąc znowu współczesnym językiem - inkluzji, to znaczy nauczania zarówno dziewcząt, jak i chłopców oraz uczniów z niepełnosprawnościami.

W związku z Komeńskim często mówi się o potrzebie kształcenia przez całe życie - od kołyski aż do śmierci. W tym całożyciowym uczeniu się najbardziej zależało mu na tym, żeby dzięki wychowaniu człowiek osiągnął życie wieczne i żeby została naprawiona zniszczona harmonia świata. Niewątpliwie oba te cele nabudowują na chrześcijańskiej wizji rzeczywistości, która swoje źródło ma w neoplatonizmie, uporządkowanym hierarchicznie zgodnie z duchem augustiańskim. Wszystko, co dzieje się w świecie - począwszy od grzesznego upadku pierwszych ludzi - tworzy kontinuum nieustannego pogrążania się w złu. Jest swoistą katagenezą. Niemniej jednak w dekadenckim procesie skrywa się możliwość zahamowania negatywnych tendencji, co więcej - odwrócenia ich kierunku ku ponownemu wznoszeniu się w górę. Zdaniem Komeńskiego, może tego dokonać jedynie człowiek. Jest to jego historycznym zadaniem i powołaniem. Żeby temu sprostać, potrzebuje on odpowiedniego wychowania.

Zgodnie z powyższym, w Wielkiej dydaktyce podkreśla się wyjątkowość ludzkiej natury, która została obdarzona zaszczytem uczestniczenia w tym, co wieczne. Człowiek posiada w pełni wszystko, co innym stworzeniom dane jest tylko w ograniczonym zakresie: „istnienie, życie, zmysły i rozum” (Komenský 1958, s. 62). To renesansowe przeświadczenie o niezwykłej godności, którą Bóg wyróżnił człowieka, kontrastuje z poglądami wielu myślicieli zarówno współczesnych Komeńskiemu, jak i wcześniejszych. Z reguły patrzyli oni na człowieka jednostronnie - np. ego cogito Kartezjusza, „pan i władca przyrody” Bacona czy imago Dei Augustyna. W odróżnieniu od nich Komeński pojmował człowieka całościowo, tzn. jako istotę obdarzoną rozumem, wolną wolą i zdolnością do działania. Jego zdaniem o człowieczeństwie nie przesądza jedynie intelekt; zależy ono również od woli, dalej, wiary oraz tego, że człowiek potrafi pracować. Takie komplementarne rozumienie człowieczeństwa wyznacza podstawę poglądów Komeńskiego na wychowanie, którego celem jest „nauczać wszystkich, aby pamiętali o swojej godności i nadrzędności, i wszystkimi środkami starali się osiągnąć własną wzniosłość" (Komenský 1958, s. 62).

W powyższym kontekście można stwierdzić, że według Komeńskiego wychowanie polega na umiejętności rozwijania w wychowanku jego człowieczeństwa, 
a konkretnie: godności, niezależności i wolności. Co prawda, wartości te zawierają się już w naturze człowieka, ale trzeba opiekować się nimi, rozwijać je i pielęgnować właśnie w okresie dojrzewania, przyjmując arystotelesowsko-tomistyczną zasadę: ars imitatur naturam - „wychowanie jest naśladowaniem natury”.

O niesztampowości stanowiska Komeńskiego świadczy moim zdaniem to, że ówcześni teolodzy reformacyjni, jak np. Martin Luter, inaczej podchodzili do kwestii wychowania. Byli oni przekonani, że człowiek z natury jest na wskroś przesiąknięty grzechem i dlatego dziecko wymaga ścisłego kierowania. Komeński twierdził natomiast, że natura człowieka nie jest w zupełności zepsuta i pomimo splamienia grzechem zachowała swoją pierwotną doskonałość. Zgodnie z tym sposobem myślenia człowiek potrzebuje wychowania jako emendatio rerum humanarum, tzn. odnowienie pierwotnej doskonałości, a właściwie naprawianie rzeczy, które ulegały degeneracji wskutek ludzkiej słabości i grzeszności (Benner, Stępkowski 2012).

Zdaniem Komeńskiego, tylko dzięki wychowaniu dana jest człowiekowi możliwość zdobycia pełni człowieczeństwa. Na to człowieczeństwo składają się trzy wymiary: (1) bycie istotą rozumną - animal rationale, (2) bycie panem stworzenia i (3) bycie obrazem Boga - imago Dei. W Wielkiej dydaktyce, wyjaśniając te trzy wymiary, Komeński (1956, s. 43) wiąże je z trzema celami wychowania - rozwijaniem mądrości, moralności i pobożności. Żeby sprostać tym celom, człowiek otrzymał od Boga trzy narzędzia: myśl, rękę i język. Myśl reprezentuje pojmowanie; ręka działanie, a język - nazywanie. Na podstawie tego zestawienia widać, że w ujęciu Komeńskiego wychowanie nie ogranicza się jedynie do przygotowania do życia praktycznego (ręka), jak przekonywali tacy myśliciele oświecenia, jak John Locke. Do osiągnięcia pełni człowieczeństwa konieczne jest rozwijanie - jeśli można tak powiedzieć - sfery ogólnoludzkiej: myślenia i mowy.

Człowiek jako istota najwyżej postawiona w dziele stworzenia powinna również obierać najwyższe cele. W Wielkiej dydaktyce Komeński pisze na ten temat następująco: „Ponieważ kimkolwiek jesteśmy i cokolwiek czynimy, cokolwiek myślimy, mówimy, tworzymy, osiągamy i trzymamy, jest wznoszeniem się ku doskonałości, stopień po stopniu; wspinając się ku doskonałości zdobywamy coraz wyższe poziomy, ale do tego najwyższego stopnia jednak nigdy nie dochodzimy" (1958, s. 63-64). To, że najwyższy i najszlachetniejszy cel pozostaje właściwie poza zasięgiem człowieka, wynika z samej jego natury. Nie powinno to jednak stanowić powodu do zrezygnowania $z$ doskonalenia siebie samego. Wprost przeciwnie ambiwalencja celu ma wzmacniać pragnienie rozwijania w sobie człowieczeństwa.

Projekt wychowania uniwersalnego przedstawił Komeński w dziele noszącym łaciński tytuł: De rerum humanarum emendatione consultatio catholica. W samym tytule autor niejako informuje, że do stawania się lepszym potrzebna jest consultatio, czyli „narada”, a po czesku porada. To sugeruje, że zmiana na lepsze nie pochodzi nigdy z góry, jako narzucona reforma czy cud z nieba. Według Komeńskiego akt stworzenia świata przez Boga był wydarzeniem jednokrotnym i niepowtarzalnym. 
Skoro człowiek zepsuł Bożą harmonię, musi ją sam odbudować - nikt go w tym dziele nie wyręczy. Mogłoby się wydawać, że to przygnębiający scenariusz - bo w jaki sposób człowiek może podołać zadaniu naprawienia świata?

Świat może znowu powrócić do swej pierwotnej harmonii dzięki podniesieniu poziomu wykształcenia ogólnego. Termin utworzony przez Komeńskiego, określający wykształcenie ogólne, to pampaedia. Taki tytuł nosi również jego obszerne dzieło, w którego centrum umieścił człowieka dążącego przez kształcenie do doskonałości (Komeński 1973). Naprawa świata dokonuje się tylko dzięki własnemu wysiłkowi człowieka, nigdy nie można jej zlecić do wykonania komuś innemu. Tak właśnie dzieje się ze stawaniem się mądrym - nikt nie może zrobić tego za kogoś innego, lecz każdy musi dożyć do mądrości samemu. Upadły świat można zmienić dzięki wysiłkowi całych generacji - wielu pokoleń, zarówno naszego, jak i następnych.

Co rozumieć pod pojęciem ludzkich spraw, które domagają się ulepszenia, wyjaśnia Komeński w Panegersii (1964). Taki tytuł nosi pierwsza część De rerum humanarum... Wyraz panegersia można przetłumaczyć jako „powszechne przebudzenie”. Odwołuje się w niej do obrazu ludzkiej natury jako zawierającej w sobie wspomniane powyżej trzy wymiary konstytuujące człowieczeństwo: (1) rozum-umysł-wolę, (2) pęd do działania i (3) wiarę. Umysł poszukuje prawdy, mądrość realizuje się w filozofii, dążenie zaś do dobra stanowi fundament pobożności i religijności. Polityka rodzi się z dążenia do uregulowania wszystkich zasad działania tak, żeby ludzie sobie wzajemnie nie przeszkadzali, lecz wprost przeciwnie - pomagali sobie. Tak więc do tego, co wymaga natychmiast i koniecznie ulepszenia, należą: filozofia, religia i polityka. Te trzy sfery są poważnie zagrożone kryzysem i ogarnięte dysharmonią. Filozofia stała się płytka, gdyż tylko spekuluje. Religia pogrążyła się w sporach o drobnostki, zamiast przebudzać wiarę w Boga. Kościoły natomiast, żądne władzy, zajmują się sprawami świeckimi. Moralność upadła, a polityka zamiast rozwiązywać sprawy wspólnego istnienia, pogrąża się w konfliktach zbrojnych.

W miejsce filozofii, rozumianej tradycyjnie jako metafizyka, Komeński proponuje pansofię, czyli mądrość prowadzącą do poznania wszystkiego. Nie chodzi mu jednak o wiedzę naukową, lecz rozeznanie w odgórnie zaprogramowanym porządku istnienia. Dzięki pansofii wojny religijne przekształca się w tolerancję i ekumenię. Komeński proponuje zwołanie światowego konsystorza. Polityka, która pozwalała na zadawanie gwałtu, straciła wiarygodność. W Anděl míru (Anioł pokoju) Komeński (1938) nawołuje do pokoju. Tej pokój jednak pojawi się dopiero wtedy, gdy każdy rozwinie wszystkie swoje możliwości, stanie się rozsądny i rozumny, będzie decydował zgodnie ze swoją wolą i zdobędzie możliwość działania. To stanowi fundament uporządkowanego świata, w którym ludzie będą mogli żyć ze sobą po ludzku. Jedną z jego fundamentalnych zasad powinno stać się to, żeby ten, kto dzierży władzę, potrafił najpierw panować nad samym sobą i był wewnętrznie zintegrowany. To sprawi, że nie będzie gubił się w nieistotnych szczegółach, nie 
będzie się rozpraszał i tonął we własnym egoizmie. Jako jednostka będzie umiał odnaleźć się „w całości” (Patočka 1998, s. 357).

Podsumowując pierwszą część prezentowanych rozważań, można powiedzieć, że Komeński nie daje gotowych rozwiązań ani nie uważa swoich propozycji za idealne, choć niektórzy uważają go za utopistę. Pragnie natomiast podzielić się z czytelnikiem bardzo ważnym dla niego doświadczeniem i zarazem odkryciem: że źródło humanizmu leży w nas samych. Człowiek jest istotą szczególną, istotą, która staje się w pełni ludzką dopiero dzięki spełnieniu swojego posłannictwa - dzięki opiece nad powierzonym mu światem. To jest przesłanie Komeńskiego skierowane pod adresem dzisiejszego wychowania.

\section{Edukacja jako troska o idee „nie z tego świata”}

Życie Emanuela Rádla przebiegało w dwu stuleciach - XIX i XX. Był on wybitnym naukowcem $z$ dziedziny nauk przyrodniczych, a równocześnie filozofem. Wykładał na Wydziale Nauk Przyrodniczych Uniwersytetu Karola w Pradze. Zmarł podczas okupacji niemieckiej w 1942 roku. Jak wiadomo, po wkroczeniu Niemców do Czechosłowacji w 1938 roku państwo to straciło suwerenność. W utworzonym przez hitlerowców Protektoracie Czech i Moraw zamknięto wszystkie uniwersytety, a studentów skazywano na roboty przymusowe bądź wywożono do obozów koncentracyjnych. Rádl tak jak Boecjusz (2006) pod koniec swojego życia napisał swoisty testament filozoficzny - Útěcha $z$ filosofie, czyli w przekładzie na język polski: Pociecha płynąca $z$ filozofii. Zostało on wydany po raz pierwszy drukiem po wojnie, w 1946 roku.

Jako filozof Rádl był myślicielem kontrowersyjnym, a równocześnie niezwykle oryginalnym. Istotności i przełomowości jego dzieła nie da się zmierzyć liczbą opublikowanych prac, lecz siłą i autorytetem osobowości. Był niezrównany w poszukiwaniu odpowiedzi na pytanie, czy człowiek potrafi pojąć ogrom swego istnienia i być świadomy swojej odpowiedzialności za własne życie.

Renomę naukową Rádl zdobył w międzywojniu przede wszystkim jako przyrodoznawca. Był cytowany w licznych dziełach przyrodniczych i antropologicznych. Z przenikliwością śledził i poddawał krytyce swoje czasy i to zarówno z perspektywy naukowej, jak i politycznej. W latach 20 . XX wieku skierował uwagę na pogarszanie się stanu kształcenia ogólnego i wszystko, co z tego wynikało. Bez zbytniej przesady można powiedzieć, że jako pierwszy dostrzegł kryzys i upadek nauki uprawianej według modelu zachodniego. W tym okresie powstało wiele jego książek. Część z nich była poświęcona ówczesnym problemom europejskiej nauki: Romantická věda (1918), Moderní věda, její podstata, metody a výsledky (1926), część kryzysowi kształcenia ogólnego - Krise inteligence (1928), w części zaś reagował na problemy świeżo powstałej nowej struktury państwowej, jaką była Czechosłowacja - O smysl našich dějin (1925), Válka Čechů s Němci (1928), Národnost jako vědecký problem (1929). 
W wymienionych powyżej pracach Rádl polemizował z poglądami najwybitniejszych osobistości życia kulturalnego i politycznego swojej epoki, do których należeli: Tomáš Garrigue Masaryk (1850-1937), Ferdinand Peroutka (1895-1978), František Xaver Šalda (1867-1937), Josef Pekař (1870-1937) czy Zdeněk Nejedlý (1878-1962).

Rádl był przekonany, że prawda jest świętością i nikt ze zwykłych śmiertelników nie dosięgnie jej bezpośrednio. Jest ona raczej wezwaniem, jakie odczuwa w sobie człowiek powołany do wejścia na drogę filozofii i pracy naukowej. Dlatego tak ważne jest zdobycie odpowiedniego wykształcenia. We wspomnianym testamencie filozoficznym Rádl mówi o tym, że prawda nie jest $z$ tego świata (1969, s. 71-72). Ten pomysł powtarza się również w jego dziełach polemicznych z drugiej dekady XX wieku (Rádl 1928a; 1928b).

W swym poszukiwaniu prawdy Rádl był bezkompromisowy. To sprawiało jednak, że pozostawał coraz bardziej osamotniony i zmuszony był żyć w izolacji. Szczególnie mocno przyczyniła się do tego kontrowersja z Masarykiem i krytyka pierwszego prezydenta Czechosłowacji. Rádl sprzeciwiał się otaczaniu uwielbieniem jego osoby i wszystkiego, co określano wówczas jako czysto czeskie, w tym tzw. czeskiej kultury narodowej. Ten kult osoby i idei czeskości wspierał, zdaniem Rádla przyrodoznawcy, pozytywizm panujący wówczas niepodzielnie na uniwersytetach.

Już w pierwszej dekadzie XX wieku Rádl wyczuwał zagrożenie pochodzące z rasizmu, i zdecydowanie występował przeciwko wszelkim jego przejawom, krytykując każdego, „kto naucza, że niektóre grupy społeczne, plemiona, z natury są wyższe od innych” (1918a, s. 291). Uzasadniał to tym, że „żaden naukowiec nie może uniknąć odpowiedzialności filozoficznej, obywatelskiej i moralnej, bo każdy, kto chciałby tego spróbować, jest człowiekiem niebezpiecznym, który prędzej czy później zaatakuje z nożem w ręku swojego bliźniego" (Rádl 1918a, s. 291).

Problematyce rasizmu Rádl poświęcił odrębną pracę - Rasová teorie a národ (Teoria ras i naród, 1918b). W dziele tym konsekwentnie odrzuca wszystkie rzekome teorie naukowe, które za podstawę przyjmują wskazane powyżej nastawienie rasistowskie. Niebezpieczeństwo tych teorii Rádl zdemaskował w czasie, gdy nikt jeszcze nie spodziewał się, co przyniesie przyszłość i jaką rolę odegra antropologia rasistowska w praktyce, doprowadzając do Holokaustu.

Z jednakową samą energią Rádl odrzucał nacjonalizm czeski i wszystkie formy szowinizmu, prowincjonalizmu i zamykania się na świat. Jako przeciwwagę eksponował światłe okresy w dziejach narodu czeskiego, kategorycznie sprzeciwiając się jednak temu, żeby z samouwielbieniem nimi się upajać. Wyrażał podziw dla ówczesnego prezydenta Masaryka, ale obawiał się jego wizji państwa narodowego (Rádl 1946b). Historię, politykę i myśl czeską pojmował jako niedające się oddzielić części historii i kultury europejskiej i światowej.

Rádl był bodajże jedynym naukowcem i publicystą, który po pierwszej wojnie światowej otwarcie postulował wzięcie pod lupę poglądów Masaryka, a zwłaszcza jego idei państwa czechosłowackiego. Podkreślał, że trzeba iść dalej niż Masaryk 
i sięgać poza jego koncepcję. Jan Patočka napisał o Rádlu, że był jedynym czeskim myślicielem, który traktował Pierwszą Republikę (tym mianem określa się przedwojenną Czechosłowacją) rzeczywiście sumiennie, poświęcając jej cały swój wysiłek, a nawet życie. Potwierdzeniem tego mogą być słowa Rádla zawarte w Krize inteligence (Kryzys inteligencji), gdzie autoironicznie pisał o sobie: „Często nachodzi mnie myśl, paradoksalna, ale tylko na pierwszy rzut oka, że ja z tym nieustannym polemizowaniem i krytyką patriotyzmu jestem jedynym człowiekiem w Czechach, któremu patriotyzm leży na sercu" (1928a, s. 26).

Według Rádla, nie da się określić, czym jest naród i kto do niego należy, ani jaka jest istota państwa narodowego. Jego zdaniem, problemu narodu nie należy rozważać jako kwestii krwi czy pochodzenia czy wreszcie rodu. Żaden znak zewnętrzny nie może decydować o przynależności do tego lub innego narodu, gdyż $\mathrm{w}$ ten sposób podchodzą do tego rasiści. Również język nie może przesądzać o narodowości, podobnie zresztą jak kultura czy wartości. Wbrew rozpowszechnionym poglądom Rádl uważał, że wszystkie wymienione składniki świadczą raczej o poziomie świadomości moralnej i politycznej jednostki niż jej narodowości. W Národnost jako vědecký problém (Narodowość jako problem naukowy) pisał, że dla człowieka państwo jest „sprawą sumienia; nie jest dziełem wieków, jest to program dla przyszłości. Narodowość określana z punktu widzenia społecznego nie jest dziełem przyrody, jest częścią całego świata, który nie istnieje, ale istnieć powinien; jest oknem prowadzącym człowieka $\mathrm{z}$ tego świata zjawisk do świata wieczności" (1929, s. 83).

Genezy Czechosłowacji jako nowego państwa w Europie Rádl nie dopatrywał się w przebudzeniu poczucia narodowego Czechów i Słowaków. Zamiast tego zachęcał, żeby zaakceptować istnienie w granicach Czechosłowacji mniejszości narodowych i odnosić się do nich sprawiedliwie, zwłaszcza do mniejszości niemieckiej. W tym kontekście krytykował biurokrację czechosłowacką za manipulowanie wynikami spisu ludnościowego. Ponadto źle odbierał dążenie, żeby ideę państwa oprzeć o tradycję narodową i „odwieczne” oczywistości. Jego zdaniem żadne państwo nie może uzasadniać swojego prawa do istnienia odrębną tradycją. Prawo do państwowości musi bowiem opierać się na wyższym ideale moralnym. Społeczeństwo tak bardzo zróżnicowane, jak czechosłowackie, może zostać scementowane jedynie jako nienarodowe państwo polityczne, które ma do tego prawo wywodzące się $z$ ideałów humanistycznych.

Jak wspomniano powyżej, konflikt $\mathrm{z}$ autorytetami politycznymi epoki doprowadził w jego przypadku do osamotnienia i izolacji. Pomimo tego nie zmienił swoich zapatrywań i swojego krytycznego nastawienia do problemów współczesności. W dziele zatytułowanym Dějiny filosofie (Historia filozofii) odniósł się do posłannictwa współczesnych mu myślicieli w następujący sposób: „Filozof rozwiązuje kłopoty swoich czasów, [...] jeżeli ma to wymiar wyłącznie praktyczny, nie jest to już filozofia" (1933, s. 35). Według Rádla, filozofia jest przede wszystkim 
wysiłkiem intelektualnym i ma sens tylko wtedy, gdy pomaga zrozumieć zmienną rzeczywistość.

Rádl pojmował historię jako zapis dziejów ducha ludzkiego, który co pewien czas zmienia kształt i wizerunek. W średniowieczu świat ducha reprezentował stan kapłański. W nowożytności rolę tę po kapłanach przejęła inteligencja. Głównym jej wyrazicielem był August Comte, twórca pozytywizmu i główny protagonista „rewolty inteligencji przeciwko duchowieństwu” (1928a, s. 6). Zdaniem Rádla, Comte’owi udało się w ten sposób zawłaszczyć katolicyzmem jako systemem myślowym i powiązaną z nim kulturą świecką, a ogłaszając naukowców kapłanami nowych czasów, samego siebie zaś ich papieżem, pozbawił człowieka bogobojności i wiary. Dzięki tej rewolcie nauka legitymizuje prawo człowieka do panowania nad światem.

Tym, co zdaniem Rádla spowodowało kryzys kultury europejskiej i zagraża jej istnieniu, jest nie tylko inteligencja i ludzie wykształceni, którzy zastąpili duchowieństwo, lecz również stechnicyzowanie owej kultury (1928a, s. 7). To ostatnie jest wynikiem jednostronności wykształcenia, której poddawany jest współczesny człowiek. W edukacji zostało mu zaszczepione błędne wyobrażenie, że dzięki technice, tzw. naukom ścisłym i ich metodom, wszystko da się zrozumieć i rozwiązać. Według Rádla, pozytywizm, marksizm i pragmatyzm wiernie odbijają to Comtowskie jednostronne pojmowanie świata.

Rosję sowiecką Rádl uważał za typowy przykład społeczeństwa i państwa zawłaszczonego przez opisany powyżej fenomen kryzysu. Jest to tym bardziej zaskakujące, że - jak wykazuje Rádl - najprawdopodobniej wyraz „inteligencja” pochodzi z Rosji. Właśnie tam - jak nigdzie indziej na świecie - napisano chyba najwięcej na temat tego, czym właściwie jest inteligencja i jakie posłannictwo ma spełniać. A jaki jest rezultat takiego postępowania? „Inteligencja błądzi po świecie, czekając, że jakiś «car» ją wyzwoli [...]. Rosja radziecka starała się obejść bez inteligencji. Jej wpływ w Europie środkowej sprawił, że ci, którzy stawiali abstrakcyjne pytania, byli wyśmiewani. Wyparte zostało wszystko, co nie dotyczyło politycznych interesów rewolucji, jej dyktatury i równości społecznej. Wiadomo, że filozofia jest w Rosji zbyteczna, że podważa się w niej znaczenie nauk duchowych i że jedynymi ideałami są tam robotnik i inżynier" (1928a, s. 9).

Z niesmakiem Rádl śledzi, jak na rynku pracy inteligencja włącza się coraz bardziej do rywalizacji w ramach konsumpcyjnego społeczeństwa kapitalistycznego, jak nie tylko konkuruje, lecz toczy otwartą wojnę o coraz lepsze warunki i możliwości rozwoju dla siebie. Interesują ją wyłącznie sprawy materialne. Przez to, zdaniem Rádla, zdradziła samą siebie i zlecone jej zadanie, zadanie historyczne i niezwykle ważne.

Zadaniem inteligencji jest bowiem tworzenie nowych myśli i idei, a przez to rozwijanie i udoskonalanie życia kulturowego, a nie tylko rozwiązywanie problemów gospodarczych i ekonomicznych. Człowiek wykształcony, powinien, zdaniem Rádla, zwracać uwagę na poważne, a nie tylko techniczne problemy, i rozwiązać je twórczo z pomocą nowych koncepcji. Zgodnie z tym ujęciem intelektualista jest 
człowiekiem myślącym samodzielnie, co oznacza, że żaden polityk (np. parlamentarzysta) ani ekonomista, nie mogą mu niczego dyktować ani dawać zleceń. Na ten temat Rádl pisze m.in.: „nie parlamentarzysta powinien być panem człowieka wykształconego, lecz to ludzie wykształceni mają dyktować warunki politykom" (1928a, s. 11). Inteligent powinien dawać zadania politykom i prawnikom i kontrolować ich wykonanie. W żadnym razie nie wolno mu dopuścić do tego, żeby politycy panowali i decydowali sami, tzn. bez żadnej instancji kontrolnej.

Zwycięstwo polityki nad kształceniem jest jedną z oznak popadania edukacji w kryzys. Dochodzi do niego dlatego, że inteligencja sama z siebie rezygnuje bądź zapomina o swoim zadaniu. Przygnębiony tym stanem rzeczy Rádl ostrzega w swojej wizji prorockiej, że nie można dopuścić, żeby wykształcenie spotkał ten sam los co katolicyzm, gdy pozytywizm z pomocą nauk ścisłych wypędził go ze świata i sam zajął jego miejsce. „Ludzkość nie obejdzie się bez stanu ludzi wykształconych, bez rządów ducha nie da się żyć" (Rádl 1928a, s. 29). Kto jednak będzie w przyszłości reprezentował rządy ducha?

Na powyższe ciekawe i zarazem paradoksalne pytanie starał się odpowiedzieć Rádl w 1928 roku w kolejnej swojej pracy pt. Revize pokrokových ideálů v národní škole (Rewizja nowych ideałów w szkole powszechnej). Przedstawił w niej znaczenie kształcenia ogólnego w nauczaniu i wychowaniu szkolnym. Swoje opracowanie Rádl zaadresował do nauczycieli szkół powszechnych - w tamtym czasie były to szkoły wiejskie i mieszczańskie. Jego zdaniem, oni właśnie powinni stać się protagonistami nowej edukacji. Trzeba wyjaśnić, że po powstaniu w 1918 roku Czechosłowacji nauczyciele, jako grupa reprezentująca młode państwo, byli otaczani szacunkiem społecznym, a nawet gratyfikowani finansowo za swoją pracę. Tym samym stracili według Rádla funkcję przewodników w kształceniu i stali się wykonawcami zadań politycznych dyktowanych im odgórnie. Rádl dezaprobuje zarówno nostalgię za tradycją i chęć powrotu do przeszłości, jak i bezrefleksyjne małpowanie nowych idei pedagogicznych. W równym stopniu zasługują, jego zdaniem, na odrzucenie - z jednej strony pajdocentryzm i wychowanie autorytarne, z drugiej zaś - fizjologiczny psychologizm, witalizm i biologizm. Działanie pedagogiczne jest specyficznym rodzaje ludzkiej aktywności, w której dwa podmioty łączą się w realizacji jednego wspólnego zadania. W tym kontekście Rádl odwołuje się do Platońskiego obrazu ,jednej wspólnej idei”, która stanowi wezwanie dla obu stron: „Idealny [...] cel wychowania to ten, który nie jest częścią tego świata, nawet nie jest wrodzony człowiekowi, jest tylko postulatem, jest miarą, którą mierzymy człowieka. Bez tej miary, która naturalnie jest na zewnątrz ucznia, nie ma wychowania z prawdziwego zdarzenia. Uczeń musi być prowadzony i napominany przez nauczyciela na podstawie wzorców absolutnych" (1928b, s. 13).

Podręczniki szkolne i plany nauczania swojej epoki Rádl oceniał z perspektywy historycznej, to znaczy według stopnia rozwoju (jego zdaniem) nauk społecznych. Autorom zarzucał, że zdradzili kwestie wychowawcze, zaniedbali moralny wymiar kształcenia, przestał ich interesować świat jako całość, zredukowali wychowanie 
obywatelskie do polityki i spraw narodowych. W niektórych podręcznikach demaskował ślady otwartego szowinizmu i nietolerancji wobec innych narodowości.

Według Rádla, sensem nauczania jest uwrażliwienie uczniów na różnicę między tym, co dobre a co złe. Wychowanie moralne jest sprawą sumienia, nie oznacza to bynajmniej, że nie można człowieka nauczyć moralnego postępowania.

W rozważaniach, w których niedwuznacznie przebija duch Platoński, Rádl zastanawia się, czy i jak przez wychowanie można wprowadzić człowieka do świata mądrości, moralności i odwagi. Podobnie jak Platon jest do głębi przekonany, że najważniejszym zadaniem wychowania jest epimeleia peri tes psyches („troska o duszę”; Pelcová 2012). W tym kontekście stwierdza: „Moralne zmagania człowieka są sprawą ludzką i żaden pragmatyzm nie sprawi, żeby było inaczej” (Rádl 1928b, s. 67).

Potomność nazywała Rádla Don Kichotem, gdyż stawał do walki przeciwko sposobowi myślenia większości; był nie tylko odważny, lecz także nie dawał za wygraną, walcząc do ostatka. To określenie nie znaczy bynajmniej, że toczył śmieszne potyczki z wiatrakami. Nie ma w nim nic pejoratywnego, a wręcz przeciwnie wskazuje na rycerską wierność do końca. Potwierdzają to słowa Josefa L. Hromádki, który napisał: „Było w nim coś z rodu Don Kichotów; był rycerzem, dżentelmenem i religijnym filozofem. Zawsze można było go spotkać tam, gdzie trzeba było stanąć przeciw krzywdzie, gdzie trzeba było odezwać się przeciwko kłamstwu i gdzie człowiek toczył walkę o rzeczy ostateczne. Rádl był ucieleśnieniem prawdziwej ludzkiej wielkości. Nadal ma nam wiele do powiedzenia” (2005, s. 18-19).

\section{Próba podsumowania}

W niniejszym studium przedstawiłam dwóch wybitnych czeskich myślicieli - Jana Amosa Komeńskiego i Emanuela Rádla. Mimo że działali i tworzyli w różnych epokach historycznych, głęboko zastanawiali się nad sprawami wychowania i kształcenia, i poważnie je przemyśliwali. Nie chodziło im tylko o to, żeby wychowanie i kształcenie człowieka spełniało kryteria utylitarne, to znaczy, żeby człowiek umiał się dostosować lub został przez innych dostosowany do wymogów społeczeństwa, w którym żyje, ani żeby szkoła dostarczała jedynie informacji potrzebnych do zdobycia i wykonywania zawodu. Koncypując edukację „inkluzyjną” i ogólną, Komeński i Rádl opowiadali się za rozwijaniem w każdym uczniu jego sił i talentów, tak żeby mógł się stać individuum, tzn. niepowtarzalną jednostką, i żeby nie uległ egocentryzmowi, który współcześnie promuje się pod hasłem indywidualizacji.

Pomimo swoistości i odmienności problemów, z którymi przyszło im zmierzyć się w swoich epokach, łączyło ich głębokie przekonanie o "transcendentnym” wymiarze wychowania i kształcenia. W swoich pismach wytrwale na ten wymiar wskazywali i z tej idei wyprowadzali swoje propozycje reform.

Ten „transcendentny” wymiar oznacza, że wychowanie ma być swoistym wtajemniczeniem człowieka w pełnię i głębię życia, rozumianego jako całość złożona ze świata, społeczeństwa i jednostki. Dzięki temu wymiarowi nauczy się on żyć 
w harmonii z samym sobą. Teorie wychowania i kształcenia, Komeńskiego i Rádla, łączy więc idea dobra i humanizmu, która, jak twierdzi drugi z nich, „nie jest z tego świata", ale nadaje mu sens i pomaga w tym, żeby świat stał się uporządkowanym systemem.

Czy takie widzenie wychowania i kształcenia może jeszcze współcześnie znaleźć zrozumienie? A może to tylko utopijne mrzonki, które już dawno straciły swoją wartość? Te pytania winny nurtować każdego, dla kogo wychowanie i kształcenie nie są tylko zawodem, lecz także powołaniem i służbą człowieczeństwu.

Przełożyła z języka czeskiego Anna Bystrzycka Przekład przejrzał i poprawił Dariusz Stępkowski

\section{Bibliografia}

Benner D., Stępkowski D. (2012). Teoretyczne i społeczne ukonstytuowanie własnej logiki nowoczesnego wychowania. Rozważania w nawiązaniu do Jana Amosa Komeńskiego i Jeana Jacques'a Rousseau. „Przegląd Pedagogiczny”, 2, s. 9-21.

Boecjusz (2006). O pocieszeniu, jakie daje filozofia. Kurylewicz G., Antczak M. (tłum.). Kęty: Wydawnictwo Marek Derewiecki.

Hromádka J. L. (2005). Don Quijote české filosofie. Emanuel Rádl 1873-1942. Brno: Marek.

Komenský J. A. (1938). Anděl míru, tłum. Hendrich J. Praha: Kalich.

Komenský J. A. (1957). Apologia Latinitatis, 3. W: tenże. Opera didactica omnia. T. IV. Pragae: Academia scientiarum Bohemoslovenica.

Komenský J. A. (1958). Vybrané spisy Jana Amose Komenského. Praha: Státní pedagogické nakladatelství.

Komeński J. A. (1964). Panegersia. W: tenże, Pisma wybrane. Remerowa K. (tłum.). Wrocław-Warszawa-Kraków: Zakład Narodowy im. Ossolińskich Wydawnictwo PAN.

Komeński J. A. (1973). Pampaedia. Remerowa K. (tłum.). Wrocław: Zakład Narodowy im. Ossolińskich - Wydawnictwo PAN.

Komeński J. A. (2015). Świat w obrazach rzeczy dostępnych zmysłom. Warszawa: Wydawnictwa Uniwersytetu Warszawskiego.

Patočka J. (1995). Tělo, společenství, jazyk, svět. Polívka J. (oprac.). Praha: ISE Oikúmené.

Patočka J. (1998). Komeniologické studie, II. Sebrané spisy, 10. Praha: Oikúmené.

Pelcová N. (2012). Wychowanie do odwagi-odwaga do wychowania. Bystrzycka A. (tłum.). „Forum Pedagogiczne”, 2, s. 41-54.

Pelcová N. (2014). Człowiek i wychowanie w refleksji fenomenologicznej. Bystrzycka A. (tłum.). Warszawa: Wydawnictwo Naukowe Uniwersytetu Kardynała Stefana Wyszyńskiego.

Rádl E. (1918a). Romantická věda. Praha: Laichterovo vydavatelství. 
Rádl E. (1918b). Rasová teorie a národ. Praha: Koči.

Rádl E. (1928a). Krise inteligence. Praha: Akademické nakladatelství YMCA.

Rádl E. (1928b). Revise pokrokových ideáli̊ v národní škole. Praha: nakladatelství akademické YMCA.

Rádl E. (1929). Národnost jako vědecký problém. Praha: O. Girgal.

Rádl E. (1933). Dějiny filosofie, I. Praha: Laichter.

Rádl E. (1946). T. G. Masaryk, hrdina nové doby. Vyprávěno chlapcưm. Praha: Vydavatelské oddělení YMCA.

Rádl E. (1969), Útěcha $z$ filosofie. Praha: Mladá fronta.

\title{
CRISIS (IN) EDUCATION AND HOW TO OVERCOME IT FOLLOWING IDEAS BY JAN AMOS COMENIUS AND EMANUEL RÁDL
}

\begin{abstract}
Education and Bildung are currently in deep crisis. To understand its essence and the possibilities of tackling the dire situation, the author refers to the thoughts of Jan Amos Comenius and Emanual Rádel. Despite the time distance, their pedagogical work remains current and inspiring.

The article consists of three parts. The first reconstructs Comenius' views regarding education and Bildung as a peculiar way of pedagogical impact and its importance in the educational process of achieving the fullness of humanity - both by an individual and by society. The second part discusses Rádel, a 2oth-century naturalist and philosopher who, like Comenius, noticed the problems of education and thought about ways to solve them. At the end, the positions of both thinkers were confronted, looking for an inspiration to overcome the contemporary crisis (in) education.
\end{abstract}

Keywords: education; Bildung, Komeński; Rádl.

Naděžda Pelcová - docent, doktor habilitowana, kierownik Katedry Wychowania Obywatelskiego i Filozofii na Wydziale Pedagogicznym Uniwersytetu Karola w Pradze, przewodniczaca Central European Philosophy of Education Society (CEPES). Wybrane publikacje: Filosofická a pedagogická antropologie (2000), Wilhelm Dilthey základy filosofie prozitku (2000), Vzorce lidstvi. Filosoficke zakłady pedagogicke antropologie (2010), Człowiek $i$ wychowanie $w$ refleksji fenomenologicznej (2014). Zajmuje się antropologią filozoficzną i filozofią wychowania. Adres korespondencyjny: M. D. Rettigové 4, Praha 1, 116 39. Adres e-mailowy: nadezda.pelcova@centrum.cz. 